\title{
Wanneer die appels ver van die boom val - Juda se geslagsregister in 1 Kronieke 2:3-4:23
}

\author{
Gerrie Snyman \\ Departement Ou Testament \\ Universiteit van Suid-Afrika \\ PRETORIA
}

\begin{abstract}
When the chip is not from the old block - the genealogies of Judah in 1 Chronicles 2:3-4:23

This article discusses the production of a genealogical text in Chronicles (I Chron. 2:3-4:23) which probably served as a key to membership within a collective community in the province of Yehud in the Persian period of the Second Temple era. The article starts with a discussion of how genealogies work in Southern Africa: firstly, within a particular church community ravished by racial tensions, secondly, within the African community during Nelson Mandela's presidential inanguration and thirdly, albeit briefly, within the context of Swazi praise songs, where the ideological role of genealogies serves to bolster traditional values. Because it is accepted that in ancient societies writing directly relates to power in ancient societies, the problem of elite groups in society is discussed before the text of I Chronicles 2:3-4:23 is analysed. The latter text is discussed with relation to Joel Weinberg's thesis of the bêt 'abôt. the strange women in Ezra and Nehemia, and the influence of the Persian administration on the inhabitants of the Ancient Near East. Finally, the elite community is seen as a group of loyal Persian administrators, despite the fact that they were (the) children of exiles.
\end{abstract}

\section{1. 'n Appeltjie vir die dors}

Die geslagsregisters in die Bybel, veral dié in Kronieke, verskaf op die oog af net 'n rits name waarvan die meeste aan die gewone leser (en maak geen fout nie, selfs die ingeligte leser!) onbekend is. Besprekings oor die geslagsregisters fokus gewoonlik op bekende persone en historiese gebeure. Die gevolg is dat lesers soms te gou 'n verband trek tussen die teks en die werklike gebeure, asof die teks 'n getroue weerspieëling van die werklike gebeure is. Hiermee wil ek nie sê dat die geslagsregisters onbruikbaar is vir die rekonstruksie van geskiedenis nie. Immers, dié kundige oor geslagsregisters in die Bybel, R.R. Wilson (1977:54-55), meen hulle is heel bruikbaar onder sekere voorwaardes. In elk geval, wat vir ons vandag na 'fiksionalisering' mag lyk, was dalk in daardie tyd aanvaarbare praktyk (vgl. Hoglund, 1997:27). Dit help nie om Kronieke se geslagsregisters af te maak as onhistories nie (vgl. Rendsburg, 1990). Die registers het sin gemaak 
vir minstens die gemeenskap vir wie die Kronis geskryf het. Vir húlle het die registers 'n geldige sosiale en juridiese basis gehad (vgl. Japhet, 1992:83).

Dit is hierdie sosiale omgewing waarbinne die geslagsregister van Juda (1 Kron. 2:3-4.23) moontlik kon gefunksioneer het, wat ek in dié artikel wil bespreek. Omdat die funksie van so 'n antieke geslagsregister moontlik nie veel verskil van die manier waarop ons ons eie familieregisters gebruik nie, begin die bespreking met die konteks wat aanleiding gegee het tot die huidige besinning oor geslagsregisters: 'n verwysing na die Postma-voorgeslag in 'n koerantbrief en die gebruik van geslagsregisters in die Afrikakultuur. Die tweede punt wat bespreek word, vloei regstreeks voort uit wat in hierdie registers blyk, naamlik dat die geslagte wat in die openbaar onthou word, dié van elitegroepe is wat op die een of ander wyse invloed uitgeoefen het. Gevolglik word die aandag op elitevorming as 'n sosiale funksie gefokus. Voordat die vraag na die funksie van elitevorming in die geslagsregister van Juda gestel word, word die register self aan die orde gestel. Hiema word die begrip vaderhuis bespreek as 'n (belangrike) sleutel om die register te verstaan, aangesien dit 'n elite daarstel wat aanspraak kan maak op die grondgebied van Juda in die tweede Tempelperiode se Persiese tydvak, oftewel die tydvak van die Achamenidiese Ryk. Ten einde 'n moontlike sosiale funksie van die begrip uit te stippel, word gekyk watter soort gemeenskap dié term kon gebruik het.

\section{Oor appels en Suider-A frikaanse bome}

\section{1 'n Suur appel ...?}

Die Gereformeerde Kerk Waterberg se weiering om mnr. Edzisani Mathobo gedurende 1996 in die gemeenskap van die kerk ${ }^{1}$ toe te laat, het die rol van "boundary maintainance" (vgl. Smith, 1991) deur geslote groepe en die status van die nageslag van stigterslede van die Gereformeerde Kerke na vore gebring. In 'n brief aan Beeld (1997-01-30) om haar verontwaardiging uit te spreek oor 'n groep Afrikaanse mans wat fisies wou verhoed dat 'n swart Gereformeerde lidmaat die erediens bywoon, sê mev. Martie Heystek (1997) (onder andere) die volgende:

Tog, dis nog stormagtig in my: Hoe kan mense wat kerk toe kom om na die verkondiging van die Woord te luister, besluit wie die kerk mag besoek?

[...]

Ter wille van die geskiedenis kan gesê word dat die kwessie van lidmaatskap van mnr Mathobo opgelos is deurdat die Gereformeerde Kerk Waterberg in Mei besluit het om tot afstigting or te gaan en nog 'n gemeente te stig. Terwyl hulle wel dieselfde kerkgebou gebruik, is die kerkdienste op verskillende tye. Mathobo woon nou die afgestigte gemeente se eredienste by. Hoewel dit in 'n koerantberig deur sommiges ontken word, meen lidmate dat die afstigting op 'n skeuring neerkom (vgl. Yssel, 1997:1) 
In my ontsteltenis kon ek net sê: 'Vandag het julle 'n dopper vrou uit hierdie kerk gedryf. My oupa-grootjie was prof. Dirk Postma. My oupa was ds. Willem Postma (Dr. O'Kulis) en my pa was ds. Willem Postma.'

[...]

Een van die manne (gelukkig weet ek nie wat sy naam is nie) sê: 'Tannie, luister bietjie hier, wil jy hê een van jou dogters moet met 'n swarte trou?'

Die onbekende man, wie se standpunt nie te ver verwyderd is van Esra en Nehemia se uitdrywing van vreemde vroue nie, speel die gevoelstroefkaart. Martie Heystek beroep haar egter op die tradisie. Dit is duidelik dat Heystek hier haar afstamming gebruik om die morele hoë grond vir haar argumente te versterk. Sy stam uit die spreekwoordelike 'adel' van die GKSA, naamlik van 'n stigterslid en sekerlik 'n groot (indien nie dié grootste nie) kerkvader van die GKSA. Maar wat is die effek van haar beroep op haar voorvaders? Miskien dat as hulle nou teenwoordig was, hulle nie sulke 'hekwagtery' sou toegelaat het nie? Wat wel duidelik blyk, is dat die voorgeslag gesag aan haar standpunt verleen, asof sy wil sê: 'Diegene wat teen hierdie standpunt is, is teen dit wat die stigterslede en hulle nageslag gedoen het' - met ander woorde, sulke mense tree op teen die 'gees' en tradisie waarmee die GKSA gestig is en deur geslagte heen bewaar is.

Ten opsigte van familie en tradisie in Afrikanergesinne sê Heese (1975:117) dat familiegehegtheid en familiebelange 'n groot rol in ons land se geskiedenis gespeel het. Sy bewering klop met die fotobeeld in die 1959-Eeufeesbundel van die GKSA (vgl. Krüger, 1959). Hierdie fotobeeld bied 'n oorsig van die geskiedenis, interpretasie en getuienis van die Gereforneerde Kerke se eerste 100 jaar. Net soos Kronieke word die wortels verder as die daadwerklike stigterslede gesoek. Waar Kronieke met Adam begin, begin dié fotobeeld met die Kolloseum en die Katakombe van St. Callisto in Rome. Die GKSA voer sy stigting terug tot by die eerste martelare van die Christelike kerk! Die byskrif by dié foto's lui nie verniet nie: "Die bloed van die martelare is die saad van die Kerk"! Daarom is benewens die groepfoto's die foto's van individuele lidmate opvallend. Hierdie foto's verwys meesal na lidmate wat om die een of ander rede 'n wesentlike bydrae tot die groei van die GKSA gelewer het, so asof die saad iets goeds opgelewer het, mense wat vir hulle onbaatsugtige diens eervolle vermelding verdien. Die meeste foto's is van lidmate wat diep spore in die Kerke en in die samelewing getrap het: Paul Kniger (Krüger, 1959:359, daar is selfs ' $n$ foto wat 'n paar uur na sy dood geneem is; Krüger, 1959:385!), J.J. Venter, 'n visepresident van die Oranje-Vrystaat (Krüger, 1959:328), en 'n paar Nasionale Party-ministers (Krüger, 1959:412).

Die fotobeeld verhef egter ook gewone lidmate tot belangrike skakels in die Gereformeerde netwerk. Van 'n Johanna Ackermann wat in 1959 reeds 101 jaar oud was, word gesê dat sy uit die Voortrekkergeslag kom met 'n pa wat die 
Blaauwkransmoord nog onthou het terwyl sy self groot ontberings gedurende die Tweede Vryheidsoorlog deurstaan het. Wat opval, is haar nageslag: 14 kinders, 46 kleinkinders, 100 agterkleinkinders, en 20 kinders in die vyfde geslag (Krüger, 1959:415). Verder is daar foto's van bekende dominees of oumas van bekende dominees. Die indruk wat hierdie fotobeeld mag laat, is dat die GKSA die eerste honderd jaar deur familiegroepe en geslagte gedra is.

Terwyl Heese (1975:117) se waarskuwing oor familieverheerliking ter harte geneem word, meen ek dat daar binne die volksmond van die GKSA ook 'n besondere aansien gegee word aan verbintenisse met die ouer kerkvaders soos Dirk Postma, Jan Lion-Cachet en J.D. du Toit. In die genoemde Eeufeesbundel word aan dié drie figure elk 'n stuk gewy (vgl. G.C.P. van der Vyver, 1959:1328; D.G. Venter, 1959:37-44 en S. du Toit, 1959:45-59). In die aansien wat aan hierdie drie figure toegeken word, is daar egter 'n tikkie ironie, want daar kleef aan hulle ' $n$ 'vreemdheid' - byna net soos by Kaleb en Jeragmeel in Juda se geslagsregister soos weergegee deur die Kronis. Kaleb en Jeragmeel se vreemdheid bestaan daarin dat hulle (vermoedelik) biologies nie van Juda afstam nie, en dat hulle eers deur die Kronis se register aan die stam verbind is (hieroor later meer. Vgl. ook Willi, 1994). Hierteenoor lê die 'vreemdheid' van die drie leiersfigure in die geskiedenis van die GKSA in etniese afkoms en religieuse dampkring. Postma en Lion-Cachet is van Nederlandse afkoms terwyl J.D. du Toit binne 'n Kaapse Nederduitse Gereformeerde agtergrond groot geword het.

Tydens die beginjare van die GKSA moes die feit dat nóg Postma nóg LionCachet boorlinge van Afrika was 'n grnot indruk op die lidmate van die GKSA gemaak het. In 1869 , tydens die vierde Algemene Sinodale kerkvergadering, het die afgevaardigdes 'n openbare verklaring oor hulle afskeiding onderteken, en wel op die volgende wyse: "Persoonlijk geteekend door al de tegenwoordige leden der Synode, eerst de Afrikaansche Broeders en daarna de Europesche" (my beklemtoning - G.S.; vgl. Krüger, 1959:356). Laasgenoemde was Postma, LionCachet en 'n ds. N.J.R. Swart, 'n Nederlander wat in 1872 die pos as goewermentsekretaris aanvaar het. In teenstelling hiermee lê J.D. du Toit se vreemdheid nie in sy biologiese afstamming nie (hy kom immers uit 'n vooraanstaande Kaapse familie). Hy is na die stigting van die GKSA gebore en hy het binne die dampkring van die N.G. Kerk groot geword. Hy kom nie uit die dampkring van die onmiddellike stigsterslede se nageslag nie en hy het hom eers in 1896 by Postma in Burgersdorp gaan aanmeld om vir predikant te studeer ( $\mathrm{S}$. du Toit, 1959:49).

\subsection{Iemand se oogappel ...}

Vanuit ' $n$ antropologiese perspektief is die gebruik van assosiasie op grond van afkoms van 'n voorouer funksioneel om konflik op morele gronde te besleg. Heystek se verwysing na haar voorgeslag herinner sterk aan die idee van 
verwantskapsvriendelikheid (kinship amity) wat baie in die verskillende Afrikakulture voorkom. Hammond-Tooke (1984:85) noem dit "the basic moral injunction to respect genealogical seniors, and sanctioned by the displeasure of the ancestor". By Heystek word bloedverwantskap en voorouerrespek vervleg met geloofsverwantskap (wat gebaseer is op broeders en susters in die geloof) om sodoende besitreg op die 'korrekte' interpretasie van die Gereformeerde tradisie te bereken.

Binne die diverse Afrikagemeenskappe van die Suid-Afrikaanse samelewing speel afstamming ook 'n groot rol. Die outobiografie van Nelson Mandela begin met 'n vertelling van sy stamverband wat 20 geslagte ver teruggehaal word by Koning Zwide aan die voet van die Drakensberge. Na my mening het ons te doen met die aanwys van 'n sibbe met 'n koning as die gemeenskaplike voorouer. Ook dié begin herinner aan die Kronis se gebruik van Adam en die GKSA se verwysing na die eerste martelare van die Christelike Kerk. By Mandela funksioneer dit om te wys op die gemeenskaplikheid van 'n klomp Afrikagroepe wat hulle afstamming na Zwide kan terugvoer. Die klem val dus eerder op dit wat die mense saambind.

Mzolo (1988:134) sê dat die doel van die opnoem van die voorvaders (veral in 'n pryslied) is om groepsolidariteit te kweek binne die groep waar elkeen die ander se broer of suster is. Hulle voel meer simpatiek teenoor persone wat aan hulle verbind word as teenoor diegene wat nie aan hulle stam verbind word nie. Binne die antropologie word gemeen dat van sibbegenote verwag word om soos bloedverwante teenoor mekaar op te tree, met ander woorde, mekaar te ondersteun op materiële en morele gebied.

Die belang van afstamming word aangedui om orde binne die gemeenskap te handhaaf: "Xhosa society was a balanced and harmonious social order in which every individual knew his or her place" (Mandela, 1994:4). Mandela stam uit 'n mindere huis (ook genoem die Linkerkantse huis of Ixhaba) van die koning. Die taak van hierdie huis was om koninklike konflik op te los. Mandela sê self hy is weliswaar lid van die koninklike huishouding, maar sy taak was nie om eendag te regeer nie. Hy is opgelei om raad aan die koning te gee. Mandela gebruik sy geslagsregister hier om enersyds 'n mite oor sy afstamming bloot te lê, naamlik dat hy uit die koninklike geslagslyn kom. Aan die ander kant lê hy 'n stuk ironie bloot: die raadgewer het die hoogste regeringsamp bereik, naamlik president.

In die pryslied wat met sy inhuldiging voorgedra is, word sy geslagsregister ingespan om sy taak as president te belig2:

2 Hierdie pryslied is goedgunstelik getranskribeer vanuit Xhosa en vertaal deur dr. Mlungisi Menziwa van die Departement Ou Testament, Unisa. 
Die slang beweeg vinnig en dapper

'n veelkoppige slang van Khangele, van Nomathokazi [se huis]

'n veelkoppige slang van Kwaliwe, van Notyatyulu [se huis]

hulle beweeg die beendere

die beendere van John Dube

die beendere van Ntondana

die beendere van Albert Luthuli

die beendere van Oliver Tambo

die beendere van die donker een, dit is Chris Hani

hulle sê: 'Keer terug na Afrika, keer terug'.

Daar is hy, die lang, rêrige lang man

van Jongintaba, van Tyatyoli, seun van Ndaba,

van Ngubengcuka, van Dalindyebo, van Mandela,

'n afstammeling van die Linkerkantse huis van Ngubengcuka, van die

familie van Varhoyi, seun van Nkonka

van daar oorkant, natuurlik, die rivier, Qunu.

Ek respekteer die vrou van die Mpemvus

wat aan ons geboorte gegee het aan hierdie aantreklike man,

ek bedoel, myself, Nosekeni,

Nosekeni, man!

Daar is dit: Rholihlahla

hierdie boog wat gespan is van die begin van die tyd

gespan van lande, gespan van Zambië.

Dit is hoekom, natuurlik, Kaunda trane stort as hy na hom kyk!

Lank [sal hy] lewe!

Dit is duidelik dat hierdie geslagsregister eerder effektiewe as biologiese verwantskap aandui: Jongintaba was hoofinan toe Mandela 'n kind was en hy het by Mandela se vader se afsterwe voogdyskap oor hom geneem (vgl. Mandela, 1994:14-23). Ngubengcuka was die hoofman wat die Tembustam in die negentiende eeu verenig het en word dus as 'stigter' van die stam genoem. Dalinyebo was regent in die begin van die twintigste eeu en die oupa van Jongintaba. Die naam Mandela in hierdie geslagsregister is dié van Mandela se oupa uit die Linkerkantse huis. As 'n mens nie weet watter rol hierdie persone in die Tembu-stamverband gespeel het nie, dan is dit maar net 'n klomp name wat afgerammel word wat een of arder voorgeslag aandui. Die name word ook nie in opeenvolging genoem nie, maar daar word begin by die hoofman wat 'n wesentlike invloed op Nelson Mandela gehad het ${ }^{3}$. Die afstamming dui hier nie op liniêre afkoms nie, maar eenvoudig op patriliniese agnatiese verwantskap met

3 Fortune (1993:177) meen dat verwysings na persone in 'n pryslied ten doel het om die voorgeslag te betrek. Dit gaan nie soseer oor wat die individu gedoen het nie. Of geslagslyste 'n kenmerk is van prysliedere, weet ek nie. Die prysliedere wat Trevor Cope (vgl. Stuart \& Cope, 1968) versamel het, het nie juis geslagslyste nie, behalwe dat elke koning se pryslied begin word met sy naam en 'n verwysing na sy pa. 
'n enkele buiging na een vrou, naamlik die moeder van Mandela, Nosekeni. Op hierdie manier probeer die imbongi diegene wat 'n rol in Mandela se opvoeding gespeel het, vereer.

\section{3 'n Ryp appel in die skoot ...}

Teenoor die onderspelery van die herkoms van 'n leier in Mandela se inhuldigingspryslied is afstamming en herkoms in Swaziland gebruik om steun vir die koningshuis te wen en op te bou. $\mathrm{Na}$ 'n tyd van afname in populariteit (vgl. Vail \& White, 1991:159) vanweè die optrede van Mbandzeni en sy seun Bhunu by die eeuwending, het Sobhuza II die eerste deel van sy regeringstyd gespandeer om Swaziland se grondsake reg te kry en om die koningshuis se mag en gesag te herstel. Volgens Vail en White (1991:161) het Sobhuza II se moeder, koningin Labotsibeni, doelbewus begin om aan die verswakte koningshuis 'n mistiek soortgelyk aan die Britse koningshuis te verskaf. Sy het dit bereik deur, onder andere, die koningshuis te verbind aan Umatalatala van 1550 en nie Dingiswayo aan die begin van die negentiende eeu nie.

Sobhuza II het self baie gedoen om die Swazikultuur te bewaar. Hy het ook die koningsgeskiedenis in sy prysliedere vir sy eie politieke doeleindes gemanipuleer. Waar die pryslied 'n meganisme van bemiddeling tussen die monarg en die volk is, het dit in sy tyd eensydig Sobhuza II se siening van 'n tradisionalistiese en koninklike Swaziland weergegee. Hiervan sê Vail en White (1991:192): "In effect, Sobhuza captured poetry, and it became a 'traditional' means of propaganda in the service of a state that overtly espouses 'tradition' in support of "traditional' monarchy."

Terwyl die geslagsregisters van Mandela en Sobhuza II oor meer as drie geslagte strek, is dit opmerklik dat dié van mev. Martie Heystek net tot die vierde geslag teruggaan. Gegewe die sosiale status van Mandela en Sobhuza II is dit in hulle gevalle nodig om afstamming meer noukeurig te bepaal, omdat hulle onmiddellike samelewing onderhewig is aan bepaalde reels van opvolging en omdat belangrike sosiale funksies aan bepaalde plekke in die geslagslinie gekoppel word. In albei gevalle kom die geslagsregister neer op die benoeming van 'n elitegroep mense op wie se skouers die wel en wee van die gemeenskap gerus het. Omdat ons in hierdie twee gevalle ook met uniliniêre afstamming te doen het, berus die afstamming sterker op nominale verwantskap. Dit beteken dat al die mense in 'n bepaalde lyn op die een of ander manier met mekaar in verband gebring word, selfs al kan reglynige biologiese afstamming nie bewys word nie. Deur almal op so 'n wyse met mekaar in verband te bring, veral onder 'n mitiese gemeenskaplike voorouer, word 'n samehorigheidsgevoel tussen 'n groot groep mense geskep. 
By die verwysing na die voorgeslagte van die GKSA vloei biologiese afstamming en geestesgenootskap ineen. Laasgenoemde word gesien in die eerste martelare van die Christelike kerk en in Calvyn op wie se gedagtes die GKSA haar bestaan uitgebou het. Die verwysing na enkele kerklidmate in die Eeufeesbundel moet in hierdie lig gesien word: hulle en hulle nasate het bygedra tot die uitbou van die geestesgoedere van Calvyn en die eerste martelare. Daarom is die werk van die Nederlandse broeders Postma en Lion-Cachet en die Nederduits-gebore J.D. du Toit van belang. Hulle het die geestesgoedere van Calvyn hier te lande kom vestig.

Uit hierdie 'sibbe' van die eerste martelare en Calvyn, in 'n tyd toe Afrikaneridentiteit die allesoorheersende element van die nasionale politiek geword het, het 'n geslag ontstaan vir wie effektiewe verwantskap lidmaatskap tot 'n elitegroep van bewaarders van geestesgoedere gegee het. Heystek se verwysing na haar Postma-voorgeslag is ' $n$ tipies Westerse manier om kognatiese afkoms aan te dui. Vir gewone mense bevat die herleiding van herkoms na een of ander belangrike persoon niks meer as 'prestigewaarde' nie. Heystek se beroep op haar vooraanstaande voorgeslag sluit by hierdie prestigewaarde aan. Sy kon natuurlik verder teruggegaan het in die Nederlandse geslaglinie of in die Afrikaanse geslagslinie, maar die waarde van Postma binne die geskiedenis van die GKSA maak enige beroep op 'n vroeëre verwantskap ongeleë. Deur spesifiek by Dirk Postma te stop, word sy in staat gestel om haar deur middel van biologiese afstamming deel te maak van 'n 'elite'-groep mense wat die GKSA van die begin af gerig het en wat sy meen nou bedreig (en beduiwel) word deur rassepolitiek. Die effek van haar beroep op effektiewe verwantskap met Dirk Postma moenie onderskat word nie. Hier is iemand, uit die geledere van daardie geslag wat gehelp het om die geestesgoedere van die GKSA tot stand te bring, wat nou waarsku dat daardie geestesgoedere gevaar loop om vernietig te word.

In die drie gebruike van geslagsregisters waarna die voorafgaande verwys het, is die emotiewe gebruik op die voorgrond. Op die een of ander manier word die voorgeslagte gebruik om die posisie van die een wat hom of haar nou daarop beroep, te regverdig. In al drie gevalle beklee daardie voorgeslagte op die een of ander wyse 'n eliteposisie. Dit is my mening dat hierdie gebruik nie veel verskil van die manier waarop geslagsregisters in die Boek Kronieke gebruik word nie. Alvorens daar na geslagsregisters in Kronieke gekyk word, word die sosiale verskynsel van elitevorming eers onder die loep geneem.

\section{Onbevlekte mooi ronde appels}

Die voorgeslagte wat onthou word, is mense wat ' $n$ invloed van een of ander aard uitgeoefen het. Invloed is juis 'n wesentlike kenmerk van elitegroepe (Cohen, 1983:66). Die benoeming 'elite' word nie altyd positief geïnterpreteer nie. Dié benaming word baie keer vereenselwig met 'n gesigslose groep mense wat 
saamsweer om gebeure te manipuleer om hulleself te pas. Verder word mense as 'n elitegroep gekategoriseer in terme van ander nie-elitegroepe of buitestanders. Daarom word met die benoeming van iemand as 'elite' 'n waardeoordeel uitgespreek.

Die benaming 'elite' dui in die engere sin op 'n regeringskliek wat mag uitoefen deur middel van 'n burokrasie (vgl. Hansen \& Parrish, 1983:263). In 'n wyer sin dui die begrip op 'n groep mense wat binne 'n sosio-kulturele konteks mag oor ander mense het en een of ander invloed op hulle kan uitoefen. Gewoonlik word die samestelling van sulke groepe bepaal deur óf afkoms, of talent, óf kultuur (Marcus, 1983:22). Maar waarop dit ook neerkom, is dat hierdie groepie(s) die gemeenskap(pe) beheer in terme van smaak, mode, gewoontes, beleid en voorregte. Hulle teenwoordigheid is egter nie standvastig nie. Daar is voortdurend 'n proses van opkoms, bloei en verval. En wanneer hulle verdwyn, laat hulle nog hulle invloed geld: 'n geval van "doctrines outliving their creators" (Marcus, 1983:42).

Die status van só 'n elite word binne die sosiokulturele konteks bepaal, met ander woorde, in 'n konteks waar elitestatus noodsaaklik is en verduur word (vgl. Greenhouse, 1983:136). Elitevorming is inherent an die mens se bestaan (Cohen, 1983:69). Omdat die elite as die meerderes beskou word, word 'n skeiding of afgesonderdheid van die nie-elite in die hand gewerk. Dit dryf die elite tot eksklusiwiteit en hulle handhaaf' $n$ afstand met ander 'gewone' groepe.

Elitevorming kom baie sterk na vore in familiebesighede of familiegroepe. Die elite-identiteit van 'n persoon hou regstreeks verband met die status van dié persoon se familie wat ' $\mathrm{n}$ aanduibare sosiale $\mathrm{krag}$ in 'n bepaalde geopolitiese terrein is (Marcus, 1983:44). In sulke groepe word die nageslag in die elitegroep ingebore en word die lede vanuit hulle geboortereg begunstig teenoor die nie-lede of werknemers. Byvoorbeeld, binne die streng kastesisteem van Indië, veral in die vorige eeu, was geboorte in die regte sosiale struktuur 'n voorvereiste om lid te wees van die elite in diens van die regent (vgl. L. Rudolph \& S. Rudolph, 1983:193, 212). Geboorte dui daar op geslagtelange lojaliteit van die betrokke familie, sodat lojaliteit gekoppel is aan bloedverwantskap.

Die sinspeling op die Postmageslag (altans die eerste vier generasies) is in hierdie artikel gemaak deur iemand van 'buite', iemand wat nie deel is van die Postmageslagslyn nie. Maar niemand sou kon ontken watter invloed die Postmas in die GKSA gehad het nie. Ek sien juis die waarde van Heystek se verwysing na haar voorgeslag as die erkenning dat hulle 'n sosiale en religieuse faktor was in die GKSA. Verder sê haar eie afstamming iets van 'n geslagtelange lojaliteit aan die tradisie van die GKSA. Wat ook na vore kom, is die afbakening van die Postmavoorgeslag as 'n groep (met 'n duidelike geskiedenis van invloed) teenoor 
'n naamlose groep wat ras gebruik om boundary maintenance binne 'n geloofsgemeenskap te doen.

Die 'elite' wat hierdie naamlose groep verteenwoordig, is gebaseer op ras. Hierdie groep was natuurlik voor 27 April 1994 (saam met Heystek) deel van die blankes wat as 'n elitegroep die politieke mag in Suid-Afrika gehad het. Die argument van hierdie groep kan daarop dui dat sommige van hulle hierdie soort mag nou binne die geloofsgemeenskap waarvan hulle lid is, wil behou. Dit lyk of die kerk die enigste terrein is waar hulle voel hulle nog hulle eliteposisie kan handhaaf. Nie dat 'n mens hulle daarvoor kwalik wil neem nie. Immers, in gemeenskappe wat elitegroepe verdra, is dit juis die primêre taak van daardie groepe om hulle eliteposisie te behou en voortdurend te legitimeer (Cohen, 1983:69). Die probleem hier is dat 'n kategorieverwarring ingetree het: 'n elitegroep in terme van ras en politiek word verplaas na die godsdiens, omdat dié soort van elitevorming op politieke terrein ongewens geword het.

Die vraag is egter: wat het elitegroepe met die geslagsregisters van Kronieke te doen? Die verband lê in die produksie van die boek Kronieke. Elitegroepe is altyd besig om hulle oorhand oor ander mense te legitimeer, te bevestig en te onderhou. Een van die maniere waarop dit gedoen word, is deur middel van wat James Scott (1990:2) die "public transcript" noem. Die "public transcript" (openbare interaktiewe diskoers) word geskep deur dié groep wat beheer oor mag het (op watter gebied ook al) en die mag na hulle wense plooi (vgl. ook Snyman, 1996 ). Met ander woorde: die teks wat op só 'n wyse tot stand kom, weerspiëel die waardes, ideologie en leiding van die beherende elite terwyl dit tegelykertyd die onderdaniges as gewillige en entoesiastiese meedoeners teken (Scott, 1990:4). Op hierdie manier kan dié groepie wat hulle in beheer sien, hulleself bemoedig en saambind terwyl hulle hulleself van hulle eie meerderwaardigheid oortuig (Scott, 1990:67).

In die tyd toe die Kroniekeboek ontstaan het, moes skrif en mag nou verbonde aan mekaar gewees het. Om skrif te hê, was om mag te hê. Davies (1992:106) dink aan 'n groep geletterdes wat hulle professie in 'n 'skool' kon uitleef. 'n Mens sou die Kronis se gemeenskappie as só 'n elite kon beskrywe, maar dan as 'n elite wat naby die Judese regerende mag gestaan het, op welke wyse ook al. Hulle sou nie geskryf het omdat dit hulle stokperdjie was nie, maar omdat dit hulle beroep was. Hulle was in diens van ' $n$ instelling (soos die tempel) vir wie hulle geskrifte nuttig sou wees. Hulle het geskryf wat die werkgewer (Judese administrasie vir die Persiese ryk) wou hêt. 'n Klaarblyklike geval van 'wie se brood 'n mens eet dié se woord 'n mens spreek'!

4 Deur verskeie soorte tekste te skryf, kon die werkgewers hul mag op verskeie gebiede vestig en behou: deur besigheidstransaksies op te teken, het die werkgewer 'n mag in die ekonomie bekom; deur argiewe by te hou, kon die werkgewer die verlede beheer; deur geskiedenis te skrywe kon 
Gegewe die gebrek aan geletterdheid in daardie tyd, moet ' $n$ mens verwag dat hierdie elitegroepie skrywers eintlik vir hulleself geskryf het. Hulle geskrifte is met die uitsluitlike doel geskryf om privaat gelees te word. Die gehoor is dus beperk en 'n mens moenie dink aan 'n wye publiek nie (vgl. Carroll, 1993:80-81). Oor die teks in die hande van 'n elitegroepie, sê Carroll (1993:81) die volgende (my kursivering - G.S.):

The Hebrew Bible is the ideological literature of an imagined community produced in the Acahemenid or Graeco-Roman period. The "imagined community' of this categorization is the construction of 'ancient Israel' and the 'first temple' nation which is the subject of the (meta)narrative GenesisChronicles. The producers of this ideological literature must be imagined to be an intellectual elite (whether priests or sages) constructing such literature in relation to their control of the temple community (I am guessing here!) [...] The 'original' Hebrew Bible served its own creators' purpose of maintaining power in their world by constructing an imagined community occupying an imagined past of which they were the inheritors. So later communities took over that ideological role of transporting the text into a charter for their own situation.

Oor die identiteit van die regerende elite sal later iets gesê word. Die standpunt wat Carroll egter stel, is dat die teks geskryf is met die doel om dié elitegroepie se mag binne die Joodse gemeenskap wat in Jerusalem ontstaan het, te bevestig en te onderhou. Die ideologiese aard van die teks noop die leser om te verstaan dat die soort Israel wat in die teks geskep word, in die eerste plek 'n poging was om die geskiedenis só te verstaan dat dit sou spreek tot die behoeftes van die gemeenskap waarbinne die teks geproduseer is. In hierdie opsig verskil die skryfproses nie veel van dié van 'n preek deur 'n predikant nie.

Die vraag wat nou beantwoord moet word, is die volgende: In watter mate word die geslagsregister van Juda in die boek Kronieke gebruik om die Joodse regerende elite se mag in Jerusalem te regverdig en te onderhou?

\section{Van Palestynse appelboom tot Joodse appelkis}

\subsection{Die appel(stam)boom}

Tradisoneel word daar onderskei tussen gesegmenteerde en liniêre geslagsregisters (Wilson, 1977:9, vgl. ook Braun 1997). 'n Gesegmenteerde geslagsregister dui meer as een lyn van afkoms van 'n voorouer aan deurdat verskillende vertakkinge of segmente in berekening gebring word. 'n Liniêre geslagsregister

die werkgewer nie net die verlede beheer nie, maar ook die eise van ander opweeg teenoor sy eie; deur onderrigtekste te laat skrywe kon die werkgewer bepaalde sosiale waardes onder die elite kweek. Deur voorspellings op te teken, kon die werkgewer ook die toekoms beheer (vgl. Davies, 1992:107). 
dui slegs een lyn van afkoms van 'n voorouer aan. Vir Wilson (1977:54) lê die waarde van 'n geslagsregister in die huishoudelike, politieke en godsdienstige perspektiewe van die produserende gemeenskap wat daarin gesien kan word. Op grond van die hedendaagse gebruik van geslagsregisters kom 'n mens agter dat 'n geslagsregister op die ou end minder sê oor die persone na wie die register verwys, as oor die verhoudinge tussen mense ten tye van die gebruik of samestelling van die register.

Die huishoudelike funksie van 'n geslagsregister kom daarop neer dat die register as 'n handves vir afkoms dien (Wilson, 1977:38-40). As 'n handves bepaal dit die posisie van 'n persoon in die gemeenskap, soos wat Mandela se posisie as stamhoof-raadgewer deur sy afstamming bepaal is. Op hierdie wyse word persone se voorregte en verpligtinge geregulcer. By Heystek is daar ook 'n aspek van 'n handves vir afkoms, so asof sy wil sê dat diegene wat met rassepolitiek die kerk wil bedryf, met haar as direkte afstammeling van die stigter van die GKSA moet rekening hou. Maar ek meen dat haar gebruik van haar afkoms meer ten doel het om beheer oor geestesgoedere uit te oefen. Wanneer die geslagsregister aangewend word om 'n gemeenskap se onderlinge verhoudinge en grondbeheer te reguleer, verkry hulle juis juridiese gesag wat met mag afgedwing kan word (Wilson, 1977:40-44). Hierdie funksie word veral aangetref waar persone op grond van erfreg sekere posisies in die gemeenskap mag beklee en sekere grond mag bekom. By Heystek gaan dit egter om wie die reg het om sekere besluite af te dwing in die naam van dit waarvoor die GKSA sedert sy stigting staan. Dit is egter opmerklik dat Heystek se gebruik van haar afkoms nie eintlik met godsdiens iets te make het nie, al gaan dit oor figure binne 'n sekere godsdienstige groepering. Haar gebruik van geslagsregisters wek die indruk van 'n sekulêre gebruik. Wilson (1977:44-45) verwys egter na die godsdienstige funksie van 'n geslagsregister wat veral by die voorvaderkultus voorkom. Die voorvaders word geag om nog 'n belang in die nageslag te hê. Die oproep om die beendere van die afgestorwe geslag te roer in Mandela se pryslied, herinner hieraan, hoewel die beendere daar na afgestorwe makkers in die bevrydingstryd verwys. In hierdie $\sin$ is die verwysing na die afgestorwe voorgeslag van die GKSA in die Eeufeesbundel en na Heystek se voorgeslag tog funksioneel: in die Eeufeesbundel word hulle werk vereer, in Heystek se verwysing word hulle verdedig.

Die geslagsregister van Juda in 1 Kronieke 2:3-4:23 is hoofsaaklik liniêr van aard, deurdat dit 'n lyn van Juda na Dawid deurtrek, met 'n beperkte segmentering om die sylinies aan te dui. Die sylinies word nie so ver as die tyd van Dawid gevoer nie, maar dit vervul dié belangrike funksie om ander mense op die een of ander manier met Juda te verbind, soos in die geval van Kaleb.

Daar is ' $n$ besliste politieke funksie aanwesig in die register, in dié sin dat die geslagsregister baie geografiese verwysings bevat. Dit begin eintlik reeds met die 
inleidingsregister van Adam tot by Noag se afstammelinge. Kartveit (1989:114115) noem dit 'n mappa mundi waarvolgens Israel die middelpunt van die wêreld is. 1 Kronieke 1:1-2:2 fokus op die grondgebied van Palestina wat vir Israel (die geslag van Jakob) uitgehou word met al die ander lede van die nageslag van Noag se gebiede rondom Palestina. Jafet word geplaas in die noorde en weste van die Ou Nabye Ooste, Gam in die suide en suidweste en Sem in die ooste en suidooste. Ismael word verbind met die noorde van die Sinaiskiereiland, Ketura word gekoppel aan die ooste en Esau word geplaas in die gebied van Edom tot by Moab.

Die geografiese fokus word verstewig deur die blik telkens te vestig op die geslagslyn waaruit Israel voortgekom het. In hierdie opsig is daar 'n duidelike huishoudelike funksie aanwesig. Die eerste twee registers volg ook struktureel dieselfde patroon (De Vries, 1989:37). Uit al die geslagte van Noag word Sem gekies. Uit al die Semitiese geslagte word Abraham gekies. Abraham is die eersgeborene uit Noag se geslag met 'n eersgeboortereg op Palestina. Sy eersgeboortereg gaan egter oor op die jongste, Jakob, en nie op Ismael of Esau nie. Ook gaan hierdie reg nie oor op Ruben nie, maar op Juda. Ook sy oudste word verbygegaan. Er, uit die Kanaänitiese vrou gebore, sterf (1 Kron. 2:3) en die geslag word verder gevoer deur Peres wie se eersgeborene, Hesron (2:5, 915), die 'voorreg' kry om die geslag tot by Dawid voort te sit.

Oor die openheid al dan nie jeens vreemdes in die geslagsregister is daar nie eenstemmigheid nie. Die register bevat heelwat name van vreemde vroue en mans $(2: 3,17,34,4: 18,22)$. Volgens Oeming (1990:121) erken die Kronis weliswaar dat vreemde elemente in die ware Israel ingetrou het, maar die manier waarop hy hierdie gevalle behandel, spreek boekdele. Dit is opmerklik dat die geslagslyn ophou die moment wat die Kanaänitiese vrou van Juda aangedui word. Er, hulle seun, sterf. Oeming (1990:121) vermoed dat hy moes sterf as produk van dié onheilige egverbintenis. Hoewel vreemdes ingetrek word, het hulle nageslag nie werklike aansprake nie 5 .

Hierteenoor staan Efrat, die weduwee van Hesron, wat die vrou van Kaleb word. Sy word beskou as 'n nie-Israelitiese. Maar uit haar kom Hur, wat die vader is van 'n hele paar stadstigters. Sesan se nageslag uit sy dogter en sy Egiptiese dienaar gaan ook voort. In albei gevalle gaan die geslag voort omdat die kinders aan die pa of die meester van die slaaf behoort (vgl. Japhet, 1993:84). Oeming (1990:122) meen egter daar is iets negatiefs te lees in die Kronis wat die Egiptenaar as't ware afgrens met die begrip 'dienaar'. Hy verwys ook na die

5 Volgens die register word geen nageslag aan Scla toegeken nie. Van die nageslag van Amasa, die seun van Abigail, suster van Dawid, en Jeter, die Ismaeliet, word geen verdere woord gerep nie. Dawid se seun Absolom, by Maäga, die Gesuriet, sterf ook. 
Kronis wat later in 2 Kronieke 8:11 Salomo se Egiptiese vrou fisies in 'n ander omgewing laat bly het.

Japhet (1993:74) meen tereg dat die vermelding van vreemde vroue dui op inklusiwiteit eerder as op eksklusiwiteit. Nasies van buite word ingebring om 'n organiese deel van die geslagte te vorm. Hieruit lei sy af dat die Kronis eerder op geografiese eenheid sinspeel as op etniese eenheid. Die geslagsregister vervul hier die rol van 'n sosiologiese kode wat 'n gemeenskap sosiaal orden op grond van geografiese gebiede en nie biologiese afstamming nie (Japhet, 1993:88). Om hierdie rede word by Kirjat-Jearim (2:53) verwys na die seuns van Sobal wat deels uit 'n ander etniese groep kom. Die verwysings na Jitriete, Putiete, ensovoorts sê dat biologiese afkoms nie die maat is waarmee gemeet word nie. Hulle is almal mense wat met die verloop van Israel se verblyf in Palestina deur die stam van Juda geabsorbeer is. Dit is ook die geval met Kaleb en sy nageslag wat tydens die ballingskap waarskynlik 'n groot rol in die omgewing van Jerusalem gespeel het, aldus Willi (1994:159). Die Kronis aanvaar dat hierdie mense ' $n$ reg op die grond van Juda het, ongeag hoe hulle daarby uitgekom het (vgl. Japhet, 1993:122).

Die toevoeging van buitestanders tot die geslagsregister van Juda het tot gevolg dat die grondgebied van Juda vergroot is. Die gebied oos van die Jordaan wat Manasse sou toekom, kom deur Magir (2:21) wat met Hesron trou, onder Judese belang. Dieselfde geld die gebied wat Kaleb en Jeragmeel eers beset het, naamlik die omgewing van Hebron en die Negevwoestyn. Die gebied waarvan hier sprake is, is egter die gebied van die naballingskapse tydperk. Hiervan sê Kartveit (1989:152): "Die Informationen z.B. über alte Siedlungen und Wohnsitze sind schliesslich auch nur um der Gegenwart willen da; die Geschichte auszulegen, heisst natürlich, sie anzuwenden."

Maar hoekom sou mense dan graag met 'n bepaalde gebied geassosieer wou word, veral die gebied van Juda, of Jehud soos dit bekend gestaan het in die Persiese ryk? Aan hierdie vraag word vervolgens aandag gegee.

\subsection{Vir wie is die appels gepluk?}

In die bespreking oor elitegroepe is beweer dat elitegroepe verantwoordelik is vir tekste wat dien om die elite se posisie en status te handhaaf (vgl. ook Carroll, 1993). Die vraag is of hulle vir hulleself geskryf het en of ' $n$ mens een of ander gehoor kan veronderstel. Al het hulle vir hulself geskryf, sou 'n mens wel kon praat van 'n implisiete of ' $n$ bedoelde gehoor, met ander woorde, dié groep mense met wie die Kronis in sy gedagtes dialoog gevoer het terwyl hy geskryf het. Gegewe die aanwesigheid van geografiese plekke, veral die formule $X$, die vader van $Y$ waar $Y$ 'n toponiem is, laat die indruk dat die implisiete gehoor diegene is wat ' $n$ plek in die naballingskapse gemeenskap gesoek het. Volgens 
hierdie redenasie sou diegene wat in Gilead gebly het, hulleself deur middel van Magir wat as die vader van Gilead (2:21) aangedui word, by die nuwe naballingskapse gemeenskap wou voeg. Diegene wat op lidmaatskap van dié gemeenskap wou aanspraak maak, moes kon aandui van wie hy afstam, waar sy linie gebly het en wie 'n noemenswaardige rol in sy linie se geskiedenis gespeel het (vandaar die verskillende anekdotes oor sommige stamlede).

Joel Weinberg (1981, 1992 en 1996) het tot dusver die meeste oor hierdie vaderhuise te sê gehad, al is daar probleme met sy benadering en formulering van die naballingskapse gemeenskap. Die begrip wat hy gebruik, is die burgertempelgemeenskap. Dié soort gemeenskap baseer hy op voorballingskapse stamverbande. Weinberg (1992:134) defimieer die burgertempelgemeenskap, oftewel bêt 'abôt, as

... an agnatic association, which united real or fictitious families, [having] a large number of members and a complicated inner structure. It necessarily included genealogies and internal solidarity. The bêt 'abôt was the result of a consciously intended convergence of the former agnatic units that were dissolved during the exile and the early postexilic times such as the mispaha. The bêt 'abôt, whose main function was social, was a form of organization that included not only laymen in the community, but the priests and Levites as well.

Dié soort gemeenskap moet egter nie vereenselwig word met dorps- en tempelbestuur nie. Hulle drie vorm almal tipologies verskillende instellings wat op die een of ander manier wel met mekaar in interaksie was (Weinberg, 1992: 61). Weinberg verbind die geslagslyste van Kronieke met die lys van teruggekeerde ballinge wat in Nehemia 7 en Esra 2 genoem word. In die Judaregister meen hy om minstens vier toponieme terug te vind (vgl. Weinberg, 1996:280281). Hierdie (beperkte) ooreenstemming gebruik hy (Weinberg, 1981:110) om aan te voer dat die geslagsregisters gebruik is om aansprake en regte binne die burgertempelgemeenskap te begrond. In die lig van die feit dat die meeste plekname uit die ou stam van Juda voortkom, meen hy dat die gemeenskap grotendeels uit mense bestaan het wat hulle afkoms na dié stam kon herlei. Omdat die lys 'n regverdiging van 'n aanspraak op die burgertempelgemeenskap in Jenusalem bied, veronderstel Weinberg (1981:112) dat hierdie aansprake verdag geraak het. Vandaar die register om dit te regverdig.

Vir Weinberg funksioneer die geslagsregister met ander woorde binne die gemeenskap wat uit die ballingskap teruggekeer het en die leiding in Jehud onder die Jode geneem het. Ondat die register gebiede insluit wat nie oorspronklik aan die voorballingskapse stam van Juda behoort het nie, ontstaan 'n vermoede dat die register opgetrek is met die oog op diegene wat nie in ballingskap was nie, maar wat by die nuwe (eksklusiewe?) gemeenskap wou aansluit. Op hierdie 
manier kon lidmaatskap gereguleer word. Weinberg (1996:280) meen juis dat die teks moontlik deur 'n skrywersgroep uit die nie-ballinge se geledere geskryf is. Hy baseer sy argument op 1 Kronieke 2:54-55 waar daar sprake is van die skrywers wat in Jabes gewoon het. Omdat hierdie verse ook die geslagsregister van Kaleb afsluit, sou 'n mens selfs kon beweer dat die register juis die insluiting van Kaleb in die nuwe gemeenskap probeer regverdig.

'n Implisiete gehoor van die geslagsregister van Juda kan gesoek word in die gemeenskap van die nie-ballinge. Weinberg (1996:280-281) meen dat die gebrek aan verwysing na die eksodus- en intogverhale wat 'n groot rol by die ballinge sou gespeel het, só 'n gehoor sou regverdig. Hy meen ook dat die oormatige klem op die Dawidsgeskiedenis nie juis vir die terugkerendes aanvaarbaar sou gewees het nie. Hulle is weggevoer as gevolg van die sondige bestaan wat die Dawidiese nasate gevoer het ${ }^{6}$. As Weinberg die boek en sy gehoor in die geledere van die nie-gedeporteerdes plaas, dan is dit asof hy eintlik wil sê in wie se hande die boek en die stof in die boek handig te pas sou kom. Sy antwoord van 'nie-gedeporteerdes' is eerder 'n antwoord op die vraag van nuttigheid as op 'n vraag oor wie die boek werklik sou gelees het, want geletterdheid was skraal. Dit is te betwyfel of ' $n$ taamlik hoë vlak van geletterdheid onder die nie-ballinge bestaan het.

Weinberg (1996:288) erken dat geletterdheid die conditio sine qua non vir die boek Kronieke is. Hy veronderstel 'n baie wyer lesersgehoor as iemand soos Davies (1992) en 'n groter toeganklikheid tot skriftelike tekste. Maar die hoë produksiekoste van tekste in daardie tyd het privaatbesit van tekste nie moontlik gemaak nie. Dit is wel waarskynlik dat die lesers en skrywers van die boek Kronieke uit 'n elitegroep mense gekom het. Die vraag is net aan watter kant van die draad 'n mens hulle moet plaas: aan die kant van diegene wat reeds binne is of aan die kant van diegene wat wil inkom? Aan hierdie aspek word nou aandag gegee.

\subsection{Wie het die appels gepluk: die eienaar of iemand van buite?}

Die indruk wat die boek laat, is dat daar 'n kontinuilteit was tussen die voorballingskapse tyd en die terugkeer van die mense uit die ballingskap, asof diegene wat weggevoer is, se plekke behou is totdat hulle teruggekeer het. Horsley (1991:170) sê dat die terugkerendes van die voormalige regerende elite afgestam het en by hulle terugkeer weer probeer het om hulle as aristokrasie te vestig, hoewel ondergeskik aan die Persiese regering:

$6 \quad$ Na aanleiding van Riley (1993) sou 'n mens ook kon sê dat die Kronis dalk verleë met Dawid was, omdat die politieke program van Dawid minder uitvocrbaar geword het in die Kronis se tyd. 
[W]e find them [the returnees - GS] reflecting a situation in which descendants of the exiles were simply re-establishing their traditional position as a 'community' of the powerful - the dominant lineages together with their retainers - for the priestly-temple apparatus which rules under Persian mandate.

Hierteenoor sou 'n standpunt geformuleer kon word vanuit Davies (1992) se skeptisisme oor dié aaneenskakeling in die agtergrond. In die lig van die ideologiese aard van die Bybelse tekste en die belang van 'n regerende elite om deur middel van die 'public transcript' die skyn van beheer te handhaaf, sou 'n belangrike dryfveer vir die teks wees wat Davies (1992:114) noem "the establishment of a national identity in which the status of the existing rulers, of recent immigration, as the indigenous élite, was secured, for their own satisfaction as much as anyone else's". Davies se siening veronderstel 'n bepaalde sosio-historiese konteks waarbinne 'n groep mense van buite af op die inwoners van Yehud afgeforseer is en hulle regeermag en bevoorregte posisie geregverdig het deur die plaaslike inwoners se gewoontes en geskiedenis vir hulleself toe te eien. Hy praat van 'n daad van ideologiese imperialisme.

Die oorwegende argument is dat daar 'n verband gelê kan word tussen die naballingskapse leierskap in Jerusalem en terugkerende ballinge. Die terugkeer was egter nie so vrywillig as wat gemeen word nie, maar geskied eerder onder druk van die Persiese owerheid wat dié gebied wou versterk as gevolg van die woelinge wat in Egipte aan die gang was. Selfs Nehemia se bouprojekte in Jerusalem, waaronder die opbou van die mure, word geag as deel van die poging om 'n bolwerk teen Egipte op te rig. Hieruit lei Hoglund (1992:234) af dat Nehemia nie so onafhanklik opgetree het as wat gemeen word nie.

Hoe dit ook al sy, Jerusalem, wat 'n belangrike skakel in die Persiese regering se grensbeleid geword het, het skielik nuwe status gekry deur ook 'n sentrum vir die invordering van belasting te word. Dié nuwe status het egter gelei tot 'n verhoogde Persiese (militêre) teenwoordigheid, gepaardgaande met 'n groter belastingslas wat die omgewing se ekonomie onder groot druk geplaas het.

Die idee dat Jerusalem se leierselite in tandem met die Persiese administrasie gewerk het, sluit nie die moontlikheid uit dat hulle wel nasate van die ballinge van die stam van Juda kon gewees het nie. Blenkinsopp (1991:53) argumenteer dat die groepie wat hulle in Jerusalem gaan vestig het, uit die boonste stand gekom het van wat hy 'die Babiloniese immigrante' noem. Hulle het wel uit die Joodse komponent gestam, maar hulle het 'n sosiale orde wat hulle in die vreemde geleer het, kom afdruk op Jerusalem. Hulle was lojaal aan die imperiale gesag en het, soos die Perse, vermenging vermy:

They reconstituted their own assembly (...), organized according to ancestral houses including free, property-owning citizens and temple 
personnel, under the leadership of tribal elders and the supervision of an imperial representative, in a cohesive social entity which, while allowing for additional adherents, was jealously protective of its status and priviliges.

Hiermee saam kan die standpunt van Smith (1991:80) genoem word. Hy kom tot die gevolgtrekking dat die gedeporteerdes 'n gemeenskap van oorlewendes was wat die militêre oorname en ballingskap oorleef het. Hy noem hulle 'n 'hibakusha'-gemeenskap. (Die naam is ontleen aan Japannees en dui op diegene wat die atoombom oorleef het). Terwyl die ballingskap self nie so rooskleurig was as wat aanvaar word nie, het dié mense weer 'n solidêre gemeenskap gevorm. By hulle terugkeer moes daar noodwendig 'n konflik met die agtergeblewenes ontstaan het, omdat hier van twee soorte ervarings sprake was.

Daar is dus goeie redes om te aanvaar dat die terugkerendes na Jerusalem (en Juda) weliswaar bande met die gebied gehad het op grond van hulle voorouers wat vroeër daar gewoon het. Dit lyk egter of die beginsel wat in die naballingskapse tyd telkens konflik veroorsaak het, die ervaring van ballingskap was.

Die ballingskapsmotief is aangewend as ' $\mathrm{n}$ manier van boundary maintenance. Mense wat nie in ballingskap was nie, moes hulle afkoms op grond van geslagsregisters bewys het. Die probleem van die vreemde vrou in Nehemia 13 en in Esra 9-10 kon juis veroorsaak gewees het deur die insluiting van vroue wat nie hulle afkoms kon bewys het nie. Om hierdie rede is hulle vereenselwig met dié volkere wat voor die ballingskap daar gebly het (vgl. Washington, 1994:232). Eskenazi en Judd (1994) meen dat die vroue dan uit die geledere van die agtergeblewenes moes gekom het. Carroll (1991:123) maak meer van die antiKanaänitiese aard van die polemiek. Hy kom egter tot die gevolgtrekking dat dit nie 'n probleem vir die elitegroep was nie, want hulle sou in alle waarskynlikheid Persiese of Babiloniese vroue gehad het. Hierdie maatreël sou hulle bevoordeel het.

Die kwessie dat sommige van die leierskapselite by sulke huwelike betrokke was, dui vir Smith-Christopher (1994:256) daarop dat die regerende groep tweespalt belewe het. Meer nog, hy meen dat die voorkoms van dié huwelike wys dat die terugkerendes hulleself nie in 'n werklike bevoordeelde posisie gesien het nie. Hy gaan uit van die standpunt dat die 'inheemse' inwoners die grond besit het, en dat die terugkerendes met die vroue uit inheemse inwoners getrou het ten einde van hierdie grond te bekom. Hy noem hierdie verskynsel "marrying up" $(1994: 260)$. Hy vermoed selfs Persiese aanmoediging hieragter, omdat die Persiese regering ondertrouery tussen die leierselemente aangemoedig het. As dit wel die geval was, het Nehemia se bevel om die vroue weg te stuur op openlike rebellie neergekom! 
Daar is egter ook (goeie?) redes waarom die regerende elite in Jerusalem nie te eng (en te gou) met die voorballingskapse geskiedenis van die gebied, en by implikasie met 'n groep terugkerende ballinge, verbind kan word nie. Met die ballingskap is die plaaslike gemeenskappe se strukture vernietig deurdat die leierskorps weggevoer is, terwyl hulle en hulle families in vreemde gebiede hervestig is. Omdat gesinne in geheel weggevoer is, was die moontlikheid van terugkeer baie skraal en was die hervestiging in vreemde gebiede baie vinniger (vgl. Oded, 1979:22). Voorts het die weggevoerdes gedien as gyselaars. Diegene wat hulle agtergelaat het se opsie tot opstand is daardeur verminder deurdat die weggevoerdes om die lewe gebring kon word. Die gaping wat ontstaan het met die leierskorps wat weg is, is gevul deur die invoer van 'n nuwe leierskorps uit ander (verowerde) gebiede (Oded, 1979:47). Die ingevoerde elemente was lojaal aan die Assiriese regering, omdat hulle welsyn in die vreemde gekoppel was aan die guns van die koning. Oded (1979:46) meen dat konflik op hierdie manier ontstaan het tussen die ingevoerdes en die agtergeblewenes. Hierdie ingevoerdes, ook dié in die Persiese tydvak, het van oraloor gekom en is gevestig waar hulle nodig was.

Onder hulle regering het daar in Palestina (en veral in die gebied wat later as die provinsie van Jehud bekend sou staan) 'n oplewing in nedersettings gekom. Opgrawings het getoon dat daar ongeveer $25 \%$ styging in vestigingsgebiede in Juda in daardie tyd was (vgl. Carter 1994) ${ }^{7}$. Dié oplewing word deur Hoglund (1991:51) geïnterpreteer as 'n uitvloeisel van die Persiese beleid om mense doelbewus op die platteland te gaan vestig, ten einde 'n ekonomie op grond van die gebied se landboupotensiaal op die been te bring en sodoende die imperiale koffers met belastinggelde te vul. Die mense wat só gevestig is, het verskillende kollektiewe ekonomiese eenhede gevorm, afgesonderd van die plaaslike bevolking. Hulle het die grond bewerk as koninklike besit. Dit het beteken dat hulle die grond kon bewerk sonder dat die plaaslike bevolking enige aanspraak op dié grond kon maak, hetsy uit hoofde van erfreg of uit hoofde van lang verblyfreg. Hoglund (1991:59) meen dat hier glad nie gedink moet word in terme van 'n gronddispuut nie, iets wat daar sou wees as die terugkerendes inderdaad gewilliglik teruggekom het en nou hulle 'erfgrond' kom opeis het. Nou was hulle egter daar onder dwang van die Persiese regering om ekonomiese redes.

Dit is nie onmoontlik dat hulle oorspronklik van die gebied kon gekom het nie. Davies (1992:82) is egter huiwerig hieroor:

7 Soos wat Carter (1994) aangedui het, was hierdie nuwe vestigingsgebiede klein. 'n Mens moet aanneem dat die algemene bevolking van Jehud minder was as die ballinge wat Weinberg (1991) meen uiteindelik teruggekom het Maar dalk sê Weinberg se optelsom iets anders, naamlik dat die Jodendom groter as Jehud is (vgl. Carter, 1994:140)! Dit is heel moontlik dat daar 'n groot groep ballinge was wat buite Jehud gaan bly het, maar tog op een of ander manier ekonomiese bedrywigheid in die provinsie ondersteun het. 
Yet it is not pig-headed scepticism that hesitates, but rather reflection and common sense. For whether originally from Judah or not, these people or their descendants would be likely to believe, or to claim that they were, indigenous. Indeed, the Persians may well have tried, in order to facilitate compliance with the process, to persuade these transportees that they were being resettled in their 'homeland', and examples of this ploy in the imperial history of humankind could be cited.

Die uitgangspunt dat Bybelgeskrifte ideologies van aard is, maak dit vir Davies moeilik om die leiers met die terugkerende ballinge te identifiseer. Persoonlik weet ek nie wat dit vir mense sou inhou om hulle te identifiseer met 'n streek waarvan hulle nie kom nie, maar Davies meen daar is genoeg Bybelverhale wat twyfel skep dat sommige inwoners van Jehud inderdaad die land as boorlinge besit het. Die geslagslys van Juda mag dalk só 'n geskrif wees, gegewe die mense wat van buite ingesluit word. Dit beantwoord egter nog nie die vraag waarom hierdie mense wat eers buite gestaan het, nou ingetrek word nie. Is dit omdat hulle nou belangrike posisies as administrateurs ter wille van die Persiese regering beklee het, en hulself in die voorballingskapse geskiedenis ingeteken het om geloofwaardigheid aan hulself te verleen? Omdat hulle die plek van die koningshuis ingeneem het, moes hulle hulle posisie regverdig. Hiervoor het hulle tradisies gebruik wat die indruk geskep het dat die enigste aanspraakmakers op die ware Israel diegene was wat vroeër in die omgewing van Jerusalem gebly het (vgl. Garbini, 1994:184), en 'n mens sou kon byvoeg, 'historiese aansprake' op die gebied gehad het. Volgens hierdie argument gebruik hulle inderwaarheid tradisies wat hulle eie posisies sou ondermyn het! Terugkerende ballinge sou dieselfde kon gedoen het en dalk met meer oortuiging. Wat ' $n$ mens egter in ag moet neem, is dat die wegvoering hulle nie ongeskonde kon gelaat het nie - hulle het vreemdelinge geword. Die weggevoerdes is ontwortel en hulle nageslag sou sekerlik 'n proses van akkulturasie ondergaan het, sodat hulle op die ou end getroue ondersteuners van die Persiese Ryk geword het en selfs die Persiese ideologie van suiwerheid aanvaar het. Al sou hulle 'n verband kon bewys met voorsate in en om Jerusalem of in die ou Juda, was hulle op die ou end meer Persies georiënteerd as Joods.

Die ontworteling moet ook baie goed begryp word. Intellektuele lewe vir die agtergeblewenes en vir die weggevoerdes het opgehou om te bestaan (vgl. ook Davies, 1992:79). Die algemene bevolking is met die wegvoering van die amptelike argief in Jerusalem afgesny. Die weggevoerdes (as regerende elite) was nie meer daar om dit te onderhou nie en die agtergeblewenes het niemand gehad wat toegang tot hierdie argiewe kon bemiddel nie ${ }^{8}$. Garbini (1994:182) sê

8 Davies dink ook nie dat die ballinge enigsins die gelcentheid gehad het (of gegun is) om van die argiefmateriaal met hulle saam te neem nie. Die gevolg van sy standpunt is dat die meeste bewerkings van Bybelse literatuur cers in die naballingskapse periode plaasgevind het! 
ook dat die Hebreeuse literatuur op sy laagste vlak was by die aanvang van die Persiese tydvak.

Briant (1987) meen dat die invloed van die sentrale Persiese regering op die plaaslike administrasie nie onderskat moet word nie. Die grootte van die ryk het veroorsaak dat hulle genoodsaak was om van die plaaslike strukture as draer van en medium vir hulle mag gebruik te maak (Briant, 1987:13). Op plaaslike vlak is die administrateurs nie met Perse vervang nie. Hulle is eerder aangevul deur administrateurs van ander gebiede. Die Perse moes egter hierdie plaaslike leierskorps in hulle geledere opneem en aan hulle voorregte gee wat hulle lojaliteit sou verseker. Stolper (1990:200) verwys na Belsunu, 'n Babiloniese amptenaar wat hoog bevorder is in die Persiese administrasie van Babilon. Hy is as vreemdeling binne die Persiese leierstand opgeneem.

Opname in die Persiese sosiale struktuur het beteken dat dié soort leiers deel geword het van 'n elitegroep mense wat Briant (1988:137) 'n "ethno-classe dominante" noem, 'n aristokrasie rondom die koning wat daarop ingestel was om hulle ideologiese, politieke en ekonomiese voorregte te verskans. Hulle het nie deelgeneem aan die 'smeltpot van kulture' wat ontstaan het uit die vele volkereverskuiwings in die Ou Nabye Ooste nie. Hierdie groep het hulleself van die res afgeskei. Dit wat aan die koninklike hof gebeur het, is op kleiner skaal gereproduseer in die ander gebiede van die ryk.

Sancisi-Weerdenburg (1990:265) meen dat die ethno-classe dominante moes uitbrei omdat die ryk vinnig gegroei het. Die ethno-classe dominante was nie staties nie en die uitbreiding van die ryk het veroorsaak dat lede van die leierskorps van die plaaslike gebiede in hulle geledere opgeneem is. SancisiWeerdenburg (1988:270) dink ook dat die kohesie van die ryk alleen geslaagd kon gewees het indien die ideologie op die hele bevolking gerig was en die plaaslike elite wat die basis van magsuitoefening op voetsoolvlak gevorm het, 'n "potential upward mobility within the political hierarchy for local elites" gebied het.

Ten einde te besluit wie verantwoordelik was vir die opstel of opname van die geslagsregister van Juda in die boek Kronieke, moet 'n mens rekening hou met die volgende:

- In die geslagsregister is daar 'n doelbewuste poging om mense wat buite die stam van Juda gestaan het, inderdaad deel van die stam te maak.

- Omdat hier sprake is van mense van buite af, moet 'n mens dalk ruimte laat vir die gedagte dat daar in die naballingskapse tydperk 'n klomp mense gearriveer het in ' $n$ gebied waarin hulle saamgegooi is binne 'n kollektief wat as 'n ekonomiese eenheid belasting moes betaal. 
- Hierdie mense is geadministreer deur 'n beherende 'elite' wat bande met die Persiese administrasie gehad het. Laasgenoemde elite het voordele gehad wat hulle sekerlik nie bereid was om prys te gee nie. Ten einde hulle eie posisie te handhaaf ten aansien van die kollektiewe wat hulle moes administreer, het hulle hulleself met die voorgeskiedenis van die gebied geassosieer.

- Die vraag of hulle werklike historiese bande met die gebied en sy geskiedenis gehad het, is 'n vraag wat meer met die etiek van hulle optrede te doen het en dalk vir die mens binne die moderniteit meer waarde het. Vir dié wat in daardie tyd geleef het, was dit nie 'n kwessie nie. Hulle het die historisiteit daarvan aanvaar.

\section{Om 'n appeltjie vir die dors te bewaar ...}

Hierdie artikel, wat meer klem gelê het op die huishoudelike en politieke funksie van geslagsregisters (van toe én nou) binne 'n samelewingsverband, het probeer aantoon watter rol 'n geslagsregister kan speel as groepe (of individue) onder druk geplaas word. Wanneer 'n geslagsregister se geldigheid binne 'n samelewing erken word, word dit gebruik om sekere aansprake te legitimeer, soos om morele hoë gesag vir die eie standpunt te werf op grond van afstamming, asof 'n persóon deur geboorte deel het aan die lojaliteit en gesag van vroeëre dinamiese lede van die gemeenskap. Dit was veral die geval van mev. Martie Heystek wat gepoog het om deur haar verwantskap aan Postma haar verset teen die naakte rassepolitiek binne die Gereformeerde gemeente waaraan sy behoort, moreel te regverdig. Haar beroep op haar voorsate het ook die sosiale rol van elitegroepe binne samelewings na vore gebring en die invloed wat hulle op die samesyn van 'n gemeenskap het, belig. Terwyl Heystek se beroep op haar voorgeslag binne die GKSA op 'n tipies Westerse wyse 'n bepaalde prestige aan haar toegeken het, het ' $n$ beroep op 'n geslagsregister binne 'n Afrikakultuur in Suid-Afrika die funksie om 'n persoon se huidige posisie te belig en te regverdig, al is dit om ideologiese redes. Dit is veral die geval met Nelson Mandela en Sobhuza II van Swaziland.

Die Kronis se aanwending van 'n geslagsregister verskil nie veel van die huidige aanwending daarvan nie. In sy geval is dit ideologies aangewend om aansprake ten opsigte van 'n eksklusiewe gemeenskap te reguleer. Hierdie gemeenskap het hulleself beskou as 'n regerende elite wat die kollektiewe in die gebied van Jehud namens die Persiese imperiale gesag bestuur het. Die vraag na die identiteit van hierdie elitegroepie, naamlik of hulle wel histories met die voormalige gebied van die stam van Juda verbind kon word, suggereer aan latere lesers die moontlikheid van 'n onegtheid in hulle geledere, so asof hulle die inheemse inwoners van die gebied kon verkul het. 'n Mens moet egter ook in gedagte hou dat die 'inheemse inwoners' ook nie almal bande met die gebied sou kon bewys nie. Die 
volkereverskuiwings van eers die Assiriërs en toe die Perse maak dit moeilik om groepe se voorgeskiedenis aan 'n gebied te koppel. Of hierdie regerende elite terugkerende ballinge was of nie, hulle was meer Persies georienteerd as Joods. Die feit is dat dit in 'n geskrif binne 'n Persiese dampkring ontstaan het - 'n geskrif wat toegang tot 'n eksklusiewe gemeenskap op 'n Persiese wyse gereguleer het. Die Perse was daarop ingestel om hulle eie identiteit te bewaar. Trouens, hulle klem op etnisiteit het aan die Nasionaal-sosialisme van Duitsland 'n groot stukrag gegee (vgl. Wiesehöfer, 1988 en 1990)! Die geslagsregister het lidmaatskap gekoppel aan die voorgeskiedenis van die gebied. Die manier waarop dit gedoen is, wek die indruk dat daar in die naballingskapse tyd groepe was wat wou lid word van die kollektiewe in die provinsie van Jehud, maar nie kon nie, omdat hulle nie afstamming kon bewys nie. Hulle kon nie wys dat hulle die spreekwoordelike appeltjies vir die naballingskapse dors gehad het nie. Die Kronis het egter op grond van geografiese verblyf, afstamming in die gemeenskap ingeteken om hierdie mense wat buite gestaan het te akkommodeer.

\section{Bibliografie}

BLENKINSOPP, J. 1991. Temple and society in Achaemenid Judah. In Davies P.R., ed. Second Temple Studies. 1. Persian Period. Journal for the Study of the Old Testament Supplement Series 117. Sheffield : Sheffield Academic Press. p. 22-53.)

BRAUN, R.L. 1997. I Chronicles 1-9 and the reconstruction of the history of Israel: Thoughts on the use of genealogical data in Chronicles in the reconstruction of the history of Israel. (In Graham, M.P., Hoglund, K.G. \& McKenzie, S.L., eds. The Chronicler as historian. Journal for the Study of the Old Testament Supplement Series 238. Sheffield : Sheffield Academic Press. p. 92-105.)

BRIANT, P. 1988. Ethno-classe dominante et populations soumises dans l'empire Achemenide: le cas de l'Egypte. (In Kuhrt, A. \& Sancisi-Weerdenburg, H., eds. Achaemenid History III. Method and theory. Proceedings of the London 1985 Achaemenid history workshop. Leiden: Nederlands Instituut voor het Nabije Oosten. p. 137-174.)

CARROLL, R.P. 1991. Textual strategies and ideology in the Second Temple period. (In Davies, P.R., ed. Second Temple Studies. 1. Persian Period. Journal for the Study of the Old Testament Supplement Series 117. Sheffield : Sheffield Academic Press. p. 108-124.)

CARROLL, R.P. 1993. The Hebrew Bible as literature - a misprision? Studia Theologica, 47:77-90.

CARTER, C.E. 1994. The province of Yehud in the post-exilic period: soundings in site distribution and demography. (In Eskenazi, T.C. \& Richards, K.H., eds. Second Temple Studies. 2. Temple community in the Persian period. Journal for the Study of the Old Testament Supplement Series 175. Sheffield: Sheffield Academic Press. p. 106-145.)

COHEN, R. 1983. Elite theory and the formation of elites among the Bura intellectuals of Nigeria. (In Marcus, G.E., ed. Elites: Ethnographic issues. Albuquerque : University of Mexico Press. p. 63-91.) 
DAVIES, P.R. 1992. In search of 'Ancient Israel'. Journal for the Study of the Old Testament Supplement Series 148. Sheffield : Sheffield Academic Press.

DE VRIES, S.J. 1989. 1 and 2 Chronicles. The forms of the Old Testament literature, Volume XI. Grand Rapids : Eerdmans.

DU TOIT, S. 1959. Jacob Daniel du Toit. (In Van der Vyver, G.C.P., red. Die Gereformeerde Kerk in Suid-Afrika 1859-1959. Gedenkboek by geleentheid van die eeufees. Potchefstroom : Die Kerkblad. p. 45-59.)

ESKENAZI, T.C. \& JUDD, E.P. 1994. Marriage to a stranger in Ezra 9-10. (In Eskenazi, T.C. \& Richards, K.H., eds. Second Temple Studies. 2. Temple community in the Persian period. Journal for the Study of the Old Testament Supplement Series 175. Sheffield : Sheffield Academic Press. p. 266-285.)

FORTUNE, G. 1993. Some recurrent structures in Shona praise poetry. (In Kaschula, R.H., ed. Foundations in Southern African oral literature. The African Studies Reprint Series Volume two. Johannesburg : Witwatersrand University Press. p. 177-186.)

GARBINI, G. 1994. Hebrew literature in the Persian period. (In Eskenazi, T.C. \& Richards, K.H., eds. Second Temple Studies. 2. Temple community in the Persian period. Journal for the Study of the Old Testament Supplement Series 175. Sheffield : Sheffield Academic Press. p. 180-188.)

GREENHOUSE, C.J. 1983. Being and doing Competing concepts of elite status in an American suburb. (In Marcus, G.E., ed. Elites: Ethnographic issues. Aibuquerque University of Mexico Press. p. 113-140.)

HAMMOND-TOOKE, W.D 1984. In search of the lineage: the Cape Nguni case. Man (N.S.), 19(1):77-93.

HANSEN, E.C. \& PARRISH, T.C. 1983. Elite versus state. Toward an anthropological contribution to the study of hegemonic power in capitalist society. (In Marcus, G.E., ed. Elites: Ethnographic issues. Albuquerque : University of Mexico Press. p. 257-277.)

HEESE, J.A. 1975. Genealogie of die studie van ons afstamming. (In Heese, J.A., Nienaber, G.S. \& Pama, C., reds. Families, familiename en familiewapens. Kaapstad : Tafelberg. p. 117-144.)

HEYSTEK, M. 1997. Op wie beroep sy haar? - Sinodebesluit is verwerp. Beeld: 6, Jan. 30.

HOGLUND, K. 1991. The Achaemenid context. In Davies P.R., ed. Second Temple Studies. 1. Persian Period. Journal for the Study of the Old Testament Supplement Series 117. Sheffield : Sheffield Academic Press. p. 54-72.)

HOGLUND, K. 1992. Achaemenid imperial administration in Syria-Palestine and the missions of Ezra and Nehemia. Atlanta : Scholars Press.

HOGLUND, K.G. 1997. The Chronicler as historian. A comparativist approach. (I/I Graham, M.P., Hoglund, K.G. \& McKenzie, S.L., eds. The Chronicler as historian. Joumal for the Study of the Old Testament Supplement Series 238. Sheffield : Sheffield Academic Press. p. 19-29.)

HORSLEY, A.R. 1991. Empire, temple and community - but no bourgeoisie! A response to Blenkinsopp and Petersen. (In Davies P.R, ed. Second Temple Studies. 1. Persian Period. Journal for the Study of the Old Testament Supplement Series 117. Sheffield : Sheffield Academic Press. p. 163-174.) 
JAPHET, S. 1992. The Israelite legal and social reality as reflected in Chronicles: a case study, (In Fishbane, M. \& Tov, E., eds. "Sha arei Talmon". Studies in the Bible, Qumran, and the Ancient Near East presented to Shemaryahu Talmon. Winona Lake Eisenbrauns p. 79-91.)

JAPHET, S. 1993. I and II Chronicles. Old Testament Library. London : SCM Press.

KARTVEIT, M. 1989. Motive und Schichten der Landtheologie in 1 Chronik 1-9. Coniectanae Biblica. Old Testament Series 38. Stockholm : Almquist.

KRÜGER, BR. 1959. Historiese foto's. Versamel en van byskrifte voorsien deur dr. B.R Krüger. (In Van der Vyver, G.C.P., red. Die Gereformeerde Kerk in Suid-Afrika 18591959. Gedenkboek by geleentheid van die eeufees. Potchefstroom : Die Kerkblad p. 311-418.)

MANDELA. N.R. 1994. Long walk to freedom. The autobiography of Nelson Mandela Macdonald Purnell : Randburg.

MARCUS, GE. 1983. Introduction (In Marcus, G.E., ed. Elites: Ethnographic issues Albuquerque : University of Mexico Press. p. 3-58.)

MZOLO, D M. 1988. Social function of clan praises ( $I n$ Nkabinde A.C, ed. Anthology of articles on African linguistics and literature. Lexicon Publishers : Johannesburg. p 133140.)

ODED, B. 1979. Mass deportations and deportees in the Neo-Assyrian empire. Wiesbaden Harrasowitz.

OEMING, M. 1990. Das wahre Israel Die 'genealogische Vorhalle' I Chronik 1-9. Beitrage zur Wissenschaft vom Alten und Neuen Testament. Stuttgart : Kohlhammer.

RENDSBURG, G.A. 1990. The internal consistency and historical reliability of the biblical genealogies. Vetus Testamentum, XL(2):185-206

RILEY, W. 1993. King and cultus in Chronicles. Worship and the reinterpretation of history. Journal for the Study of the Old Testament Supplement Series 160. Sheffield : Sheffield Academic Press.

RUDOLPH, L.I. \& RUDOLPH, S.H. 1983. Oligopolistic competition among state elites in princely India. (In Marcus, G.E., ed. Elites: Ethnographic issues. Albuquerque : University of Mexico Press. p 193-220.)

SANCISI-WEERDENBURG, H. 1988. Was there ever a Median empire? (In Kuhrt, A. \& Sancisi-Weerdenburg, H, eds. Achaemenid History III Method and theory Proceedings of the London 1985 Achaemenid history workshop. Leiden : Nederlands Instituut voor het Nabije Oosten. p. 197-212.)

SANCISI-WEERDENBURG, H. 1990. The quest for an elusive empire. (In SancisiWeerdenburg, H. \& Drijvers, J.W., eds. Achaemenid History V. The roots of the European tradition. Proceedings of the 1987 Groningen Achaemenid history workshop. Leiden : Nederlands Instituut voor het Nabije Oosten. p. 263-274.)

SCOTT, J.C. 1990. Domination and the ants of resistance. Hidden transcripts. New Haven : Yale University Press.

SMITH, D.L. 1991. The politics of Ezra: Sociological indicators of postexilic Judaean society. (In Davies P.R, ed. Second Temple Studies. 1. Persian Period. Journal for the Study of the Old Testament Supplement Series 117. Sheffield : Sheffield Academic Press. p. 73-97.) 
SMITH-CHRISTOPHER, D L 1994. The mixed marriage crisis in Ezra 9-10 and Nehemiah 13: a study of the sociology of the postexilic Judaean community. (In Eskenazi, T C. \& Richards, KH., eds Second Temple Studies. 2. Temple community in the Persian period. Journal for the Study of the Old Testament Supplement Series 175. Sheffield : Sheffield Academic Press. p. 243-265.)

SNYMAN, G.F. 1996. Carnival in Jerusalem. Power and subversiveness in the early Second Temple period. Old Testament Essays, 9(1):88-110.

STOLPER, M.W. 1990. The KASR archive. (In Sancisi-Weerdenburg, H. \& Kuhrt, A. eds. Achaemenid history IV. Centre and periphery. Proceedings of the Groningen 1986 Achaemenid history workshop. Leiden : Nederlands Instituut voor het Nabije Oosten. p. 195-205.)

STUART, J \& COPE, T. 1968 . Izibongo. Zulu praise-poems. Collected by James Stuart. London : Oxford.

VAIL, L \& WHITE, L. 1991. Power and the praise poem. Southern African voices in history. Charlottesville : University Press of Virginia.

VAN DER VYVER, G.C.P. 1959. Ds. Dirk Postma - God voorsien in 'n uur van nood. (In Van der Vyver, G.C.P., red. Die Gereformeerde Kerk in Suid-Afrika 1859-1959. Gedenkboek by geleentheid van die eeufees. Potchefstroom : Die Kerkblad. p. 13-28.)

VENTER, D.G. 1959. Jan Lion-Cachet. (In Van der Vyver, G.C.P., red. Die Gereformeerde Kerk in Suid-Afrika 1859-1959. Gedenkboek by geleentheid van die eeufees. Potchefstroom : Die Kerkblad. p. 37-44.)

WASHINGTON, H.C. 1994. The strange woman of Proverbs 1-9 and post-exilic Judean society. (In Eskenazi, T.C. \& Richards, K.H., eds. Second Temple Studies. 2 Temple community in the Persian period. Journal for the Study of the Old Testament Supplement Series 175. Sheffield : Sheffield Academic Press. p. 217-242.)

WEINBERG, J. 1981. Das Wesen und die funktionelle Bestimmung der Listen in $1 \mathrm{Chr}$ 1-9. Zeitschrifi für die altrestamentliche Wissenschaft, 93:91-114.

WEINBERG, J. 1992. The citizen-temple community. Transl. by Daniel. L. SmithChristopher. Journal for the Study of the Old Testament Supplement Series 151 Sheffield : Sheffield Academic Press.

WEINBERG, J. 1996. Der Chronist in seiner Mitwelt. Berlin : De Gruyter.

WIESEHÖFER, J. 1988. Das Bild der Achaimeniden in der Zeit des Nazional-Sozialismus (In Kuhrt, A. \& Sancisi-Weerdenburg, H., eds. Achaemenid History III. Method and theory. Proceedings of the London 1985 Achaemenid history workshop. Leiden Nederlands Instituut voor het Nabije Oosten. p. 1-4.)

WIESEHOFER, J. 1990 Zur Geschichte der Begriffe 'Arier' und 'Arisch' in der deutschen Sprachwissenschaft und Althistorie des 19. und der ersten Halfte des 20. Jahrhunderts. (In Sancisi-Weerdenburg, H. \& Drijvers, J.W., eds. Achaemenid History V. The roots of the European tradition. Proceedings of the 1987 Groningen Achaemenid history workshop. Leiden : Nederlands Instituut voor het Nabije Oosten. p. 149-166.) 
WILLI, T. 1994. Late Persian Judaism and its conception of an integral of Israel according to Chronicles: some observations on form and function of the genealogy of Judah in 1 Chronicles 2:3-4:23. (In Eskenazi, T.C. \& Richards, K.H., eds. Second Temple Studies. 2. Temple community in the Persian period. Journal for the Study of the Old Testament Supplement Series 175. Sheffield : Sheffield Academic Press. p. 146-162.)

WILSON, R.R 1977. Genealogy and history in the biblical world. New Haven : Yale University Press.

YSSEL, E. 1997. Waterberg-gemeente verdeel in 2; ontken skeuring is oor swart lidmaat Beeld: 1, Mei 9. 
